\title{
Optimization of the Civic Education as the Effort to Strengthen National Character in Multicultural Community
}

\author{
Arie Supriati ${ }^{1}$, Mardan Umar $^{2}$ \\ Pancasila dan Civic Education Department \\ Manado State University \\ Tondano, Indonesia \\ 1 ariesupriati2017@gmail.com, ${ }^{2}$ mardanumar@unima.ac.id
}

\begin{abstract}
Civic Education has a strategic role in strengthening the character of Indonesia that has diversity in its tribes, religions, races and classes. Therefore, the optimization of civic education as a subject is very important and needs to be continuously improved. Thus, the study will examine the optimization of civic education as the effort to strengthen the nation's character in multicultural society with the object of research in Senior high school (SMA) especially in SMA Negeri 7 Manado. The method was qualitative-descriptive method with data collection technique through observation, interview and documentation data. The results of the study indicate that the implementation of Civic Education in SMA Negeri 7 Manado is quite optimal with the existence of school programs that emphasizes the aspects of character, student activities and interaction in school environment in their learning process.
\end{abstract}

\section{Keywords-civic education; multicultural; national character}

\section{INTRODUCTION}

The end of the Soeharto era and move to the reformation era has given freedom to the existence and the development of personal and group identity. People express their freedom in their own way. Even though, at the end, it may give negative effects for their nation and state life. The discourse of Indonesian multiculturalism was born due to decentralization that encouraged the increase of cultural identity boundaries (ethnic, religion and class), then the cultural boundaries triggered a conflict that harmed national unity [1]. This is what drives the issue of the integration of the nation by strengthening the four pillars of nationality namely NKRI, Pancasila, 1945 Constitution and Bhineka Tunggal Ika. As a pluralistic nation, Indonesian has a responsibility to maintain the diversity in it as a resource for building the nation. Pluralism of the nation should be interpreted as the characteristic of Indonesia that is able to coexistence peacefully among ethnics, religious, racial and group differences. This is the main spirit of multiculturalism, which is to live together peacefully.

Indonesia is known as a country with a challenge in cultural diversity. This can be seen from the existence of various cultures that exist in Indonesia. This characteristic of Indonesia can be strength for the nation in building the future of a developed, civilized, and socially equal country in a frame of unity. Recently, however, there have been many occasions that show discriminatory attitudes, intolerance and tend to fight among different groups of people. Several researches, such as the report from Survey Circle Indonesia and Denny J.A Foundation have showed data about the beginning of the decreasing level of public awareness in multicultural life [2, 3] discuss about the inconvenience of society if they are living side by side with different members of society. Similarly, SETARA Institute, ELSAM and The Wahid Institute data that report the cases of violations of religion freedom from 2014 to 2016. These data show that an understanding of the importance of peaceful coexistence in multicultural societies needs to be taken seriously.

In the local context, the people of Manado City also have different ethnics, religions and groups coming from Minahasa, Bolaang Mongondow, Gorontalo, Sangihe Talaud, and Gorontalo which become part of Manado city residents. This diversity can bring great potential in regional development when every element of society synergizes to provide the best for their region. Conversely, differences in multicultural societies can also have a negative impact with the threat of conflict and division between groups and community members.

To build a character of united nation and respect the differences in society, education process is one of the ways that can be used to give learners a good understanding and attitude toward living in a multicultural society, as stated in one of the pillars of UNESCO "education is learning to live together". Education must be able to unite all elements of the nation from various backgrounds. Yusuf argues that education must be at the forefront of unity and integration of the nation [4]. Education must be able to be the heir of universal values that are useful for people's lives, especially multicultural societies.

Therefore, there needs to be an effort to strengthen the understanding of citizenship related to socio-psychological aspects which is the object of the development of Civic Education. According to Budimansyah \& Suryadi, aspects of civic education can be reconceptualized into civic knowledge, reflective critical thinking skills, problem solving, decisionmaking and other social skills [1]. The implications on the 
learning process of Civic Education is the aspects of knowledge, attitude and social skills must be priority to strengthening the national character of Indonesia. To instill the values of these characters, the implementation of Civic Education needs to be optimized to strengthen the nation's character to face the challenges and threats of conflict in multicultural societies.

\section{THEORETICAL REVIEW}

\section{A. Concept of Civic Education and Multiculturalism}

Civic Education has a strategic role in multicultural community. Civic Education and Citizenship education is a process to nurture citizens to have good behaviour. Citizenship education is the whole process of education towards the formation of a person's character as a good citizen $[5,6]$. Citizenship education is the product of the whole school education program [5].

Civic Education as a subject becomes one of the ways for the development of attitude and character of multicultural nation. Therefore, Cogan \& Derricott through the idea of Multidimensional Citizenship mentions several characteristics of citizens that can be utilized to form learners who respect differences in society such as attitudes to see and understand the problems as members of the global community, have the ability to work with other in a cooperative way, understand, accept, respect cultural differences, have the capacity to think in a critical and systematic way, have a desire to resolve the conflict in a non-violent way, and protect human rights [6].

Cogan proposed the Multi Dimentional Citizenship (MDC) as a model for civic education in multicultural society [1]. MDC consists of four interrelated dimensions: personal dimension, social dimension, spatial dimension and temporal dimension as shown in figure 1 . These four dimensions of citizenship serve as a reference to describe the competencies of every citizen or multicultural citizen.

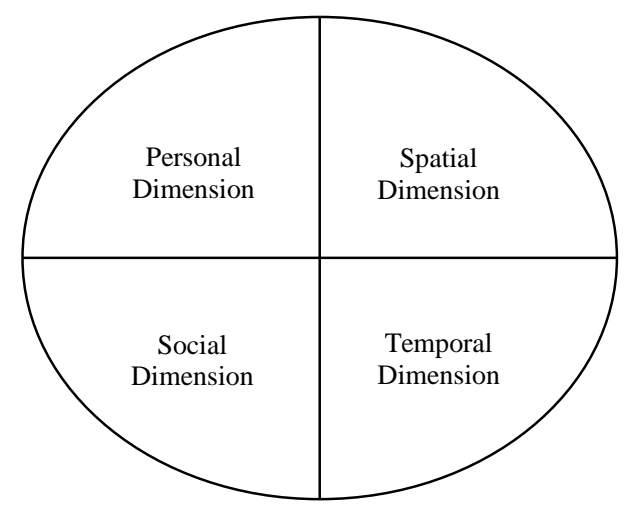

Fig. 1. Four dimensions of multidimensional citizenship [1].

Based on figure 1, the personal dimension includes thoughts, feelings and actions. In civic education, learner's personalities consist of a diverse set of backgrounds. The social dimension, that places social activity as a citizenship activity. This dimension is manifested in one's social activities in society such as participating in handling community problems, political activity and other civil activities. The spatial dimension, is the fact that the modern world demands citizens to be members of communities as a global entity. Multidimensional citizenship requires people to be able to live in all spheres of life. The temporal dimension of citizenship provides an understanding that in solving social problems.

The embodiment of the citizenship dimension in Civic Education learning needs to be aligned with the overall school education program. The alignment can be seen from the curriculum, learning program, learning strategies and methods and evaluation techniques. In regard to Multiculturalism, Civic Education has a very strategic role in addressing the condition of Indonesian society.

The diversity and multiculturalism of Indonesian society cannot be ignored, all aspects need to get a serious attention to in order to make it as a resource in building the nation. Kellert states that diversity and plurality exist should also recognize the equal rights that are binding for all beings [7]. Therefore, Mahfud emphasized the multicultural understanding to unite Indonesia in their differences and diversity [8]. This is where the role of education in providing a good understanding of the importance of living together in differences as a nation.

\section{B. National Character}

Hornby and Parnwell, mention that character as a mental or moral quality, and moral strength [9]. According to Lickona, character is the possession of the good things [10, 11]. Character is a good objective of human quality, so the content of a good character is good thing like honesty, courage, justice and compassion. Zulkarnain cites Lickona's opinion about character as universal values, included respect and courtesy, generous, helpful help and mutual cooperation, and tolerance, peace and unity [12].

Lickona further explains that the issue of character is a shared responsibility, not only the responsibility of the school, but also the responsibility of the parents $[10,11]$. Character is very beneficial for social life because for Lickona characters work in the social environment not in an empty space [13].

Based on that description, character should be interpreted as a collection of values that are used as guidance and reference in thinking, behaving, and acting in every activity of life is always based on the character values. Indonesia as a nation that is filled with values of life derived from the religion, culture, or traditions of Indonesian society since the ancient times. These values become universal values that are believed by all Indonesian people.

In relation to Civic Education, We refer to the values of Pancasila as the basic value of thinking, behaving, and acting. Deity, Humanity, unity, deliberation, and justice are the main values underlying the nation's movements. This should be reflected in every citizen activity, so it is necessary to apply the values of Pancasila as the nation's character as a whole through education. 


\section{Efforts to Optimize Civic Education}

National Education has explicitly placed the nation's character building as an important part of education in Indonesia, Article 3 of the National Education System Act states that national education functions to develop the ability and shape the character and civilization of the nation. Similarly, the purpose of national education which generally focuses on the values of the nation's character. Therefore, strengthening the character of the nation needs to be done in a structured and well programmed. One of the efforts that can be done is optimizing Civic Education in the school environment.

Lickona suggests the important role of schools in shaping culture of educational environment that supports character building [14]. Strengthening the Character of the Nation in the school environment has several objectives: a) Developing the values of life; b) correcting learners' behavior; and c) Establish harmonious connections with families and communities as a form of shared responsibility in character education of the nation [15]. Furthermore, Banks suggests the efforts that educational institutions can adopt in the cultivation of attitudes and behaviors of respecting differences in society are content integration, knowledge construction, prejudice reduction, equity pedagogy or human equality in education and empowering school culture [16, 17].

In addition, schools should establish partnerships with families and the environment so that all school programs can be properly implemented. Mutual cooperation between schools, families and communities should be a spirit in fostering the character of Indonesia's young generation through Civic Education. This cooperation will ensure that every educational process works.

\section{METHOD}

This study was designed using qualitative descriptive research as Merriam put forward some assumptions about qualitative research, so researchers will focus more on the process, focus on meaning and experience and will more physically interact with people, location, or institutions to observe or record behavior that is in the background of study [18]. This study puts the researcher as the key instrument of Sugiyono, sampling of data source is done by purposive and snowball [19].

Data of this study are Students and Civic Education teachers at SMA Negeri 7 Manado. The data were collected from January to February 2018 using data collection; observation techniques to the Civic Education learning process as a strengthening to character in SMA Negeri 7 Manado. Afterwards, interview was conducted with the teachers based on the instruments that have been prepared, as well as collecting documentation data. The data analysis is inductive/qualitative in which the researchers conducted an analysis of the research findings. This data analysis technique is done with three flow of activities, namely data reduction, data presentation, and conclusion [19]. Researchers conducted a qualitative data analysis according to interviews and observations and then display data descriptively.

\section{RESULT AND DISCUSSION}

SMA Negeri 7 Manado has a school vision which is "Berilmu, Beriman dan Berbudaya lingkungan" (knowledgeable, faithful, cultured environment). In general, this school has diversity in many aspects whether in ethnicity, religion, or class. Students studying at this school are not only come from Manado, but also from Minahasa, Sangihe, and other districts. This indicates the need for education that considers multicultural aspects.

There are 2 Civic Education Teachers in SMA Negeri 7 Manado. While the existing students in SMA Negeri 7 Manado come from majority the city of Manado and Minahasa and some come from areas of outside North Sulawesi. From the ethnic backgrounds, most students come from the Minahasa ethnic, then Gorontalo and Sangihe, and minor part comes from ethnic that is outside North Sulawesi. In religious background, Protestant Christian $60 \%$, Islam $30 \%$ and $10 \%$ are Catholic, Hindu and Buddhist.

School programs are arranged regularly in school education plans. One of the developed culture is "Senyum, Salam, sapa" (Smile and Greet). In practice, teachers and students are engaged in a harmonious and family-friendly atmosphere. Smiles as a sign of hospitality will provide comfort to all the citizens of the school. Greeting is a form of respect to others without distinction of ethnics, religion, or classes. The school culture aims to create a peaceful, togetherness, kinship, and mutual respect for the school environment.

Implementation of Civic Education seeks to develop student character that reflects the values of multiculturalism and also upholds the integration of the nation. Student character development is integrated in the subject of Civic Education and other subjects. Efforts are made to internalize the values of nation's character in the subjects, provide good example where the teacher becomes a role model.

Students' activities that reflect the spirit of respect for differences are evident in school interactions and tolerance in various religious activities. For Muslim students, counseling is focused in the Organisasi Kerohanian Islam (Rohis), while Christians are in the Organisasi Pelayanan Siswa (Pelsis). This student organization, together organizes activities that aim at fostering religious attitudes and character, discipline and responsibility.

School support is excellent in character building. The involvement of principal and teacher and all elements of the school have given a positive effect on strengthening student character. Nevertheless, civic education has not specifically had a character education program. One thing that stands out from this school is its concern for the environment. This resulted in the predicate as SMA Adiwiyata Mandiri (ecofriendly school) and became a pioneer of green community at several schools in Manado.

Civic education has a great responsibility to prepare learners to be individuals who value differences in a multicultural society. So, Civic Education should provide students with knowledge about multiculturalism, so that they can show a positive attitude of life in addressing differences. The attitude of life should be started immediately through 
habituation in the educational environment. Thus, the process of Citizenship Education in the context of subjects, should be directed to the conduction of a conducive learning situation and appreciate the values of multiculturalism.

In accordance with the results of the study, SMA 7 Manado has made efforts to strengthen the character of students through school programs, learning activities, student activities and interactions in school environment. This shows that the implementation of Civic Education is already optimally implemented in SMA 7 Manado although there are some things that still need an improvement, for example; forming a community of students that campaign the importance of respecting others in diversity.

The school community plays a huge role in the process of training and habituation of student characters. As Lickona views who put forward six elements in shaping a culture of educational environment that supports the development of character [14]. The involvement of leaders of educational institutions becomes important in enforcing the rules in the educational environment. Similarly, there is a community in the school that pioneers a peaceful life in difference. This will support the birth of awards, justice and cooperation of all elements of the school. Thus, efforts to build the nation's character through schools have a great opportunity. School as a learning environment is a small community that becomes a place to train attitudes and characters before entering into a wider society. Therefore, good education in the school environment will be a useful provision for students facing greater social interactions of heterogeneous communities within the nation and the state.

From the interaction in the environment of SMA 7 Manado, there are several conditions that correspond to the multidimensional citizenship idea from Cogan \& Derricott [6]. This is evident from the attitude of students who respect the differences between students, have the ability to cooperate in a cooperative way, understand, accept, and appreciate cultural differences. This is very beneficial in supporting civic education learning process which is oriented on the development of student character in multicultural society both within the scope of the school and in the social environment of the community. The school atmosphere of a harmonious, religious, fair, family-friendly environment, mutual respect for each other is a reflection of the values of Pancasila which is the view of life of Indonesia. This is the character of the nation that needs to be improved continuously through Civic Education.

\section{CONCLUSION}

In accordance with the description presented, it can be concluded that Civic Education in SMA Negeri 7 Manado is considered quite optimal in developing students' character. Strengthening character through Civic Education is done through classroom activities, student activities, school culture, and interaction among all elements of the school. This becomes a valuable provision for students in facing multicultural society life. Students will understand better the benefits of peaceful coexistence, respecting each other as citizens who have the same rights, and then behave in accordance with the noble values of the nation as stated in Pancasila.

\section{REFERENCES}

[1] D. Budimansyah dan K. Suryadi, PKN dan Masyarakat Multikultural, Bandung: Program Studi Pendidikan Kewarganegaraan, 2008.

[2] M.M. Iqbal, "Pendidikan Multikultural Interreligius: Upaya Menyemai Perdamaian dalam Heterogenitas Agama Perspektif Indonesia," Jurnal Sosio Didaktika, vol. 1, no. 1, pp. 89-98, 2014.

[3] M. Umar, "Internalisasi Nilai Kedamaian melalui Pendidikan Kedamaian sebagai Penguatan Pembangunan Karakter pada Masyarakat Heterogen," Jurnal Waskita, vol. 1, no. 1, pp. 77-97, 2017.

[4] H.A. Yusuf, "Promoting Peaceful Co-Existence and Religious Tolerance through Supplementary Readers and Reading Comprehension Passages in Basic Education Curriculum," International Journal of Humanities and Social Science, vol. 3, no. 8, 2013.

[5] J. Allen, "The Role of Ninth Grade Civics in Citizenship Education," The High School Journal, vol. 44, no. 3, pp. 106-111, 1960.

[6] J.J. Cogan dan R. Derricott, Citizenship for the 21st Century: An International Perspective on Education, London: Kogan Page, 1998.

[7] S.R. Kellert, Connecting with Creation: The Convergence of Nature, Religion, Science and Culture. Journal for the Study of Religion, Nature and Culture, 1.1 pp. 25-37. London: Equinox, 2007.

[8] C. Mahfud, Pendidikan Multikultural, Yogyakarta: Pustaka Pelajar, 2008.

[9] E. Gunawan, Pendidikan Karakter, Konsep dan Implementasi, Bandung: Alfabeta, 2012.

[10] T. Lickona, Character Matters (Persoalan Karakter), Penerjemah: Juma Abdu Wamaungo \& Jean Antunes Rudolf Zein. Jakarta: Bumi Aksara, 2013.

[11] T. Lickona, Educating For Character, Mendidik Untuk Membentuk Karakter. Penerjemah: Juma Abdu Wamaungo. Jakarta: BumiAksara, 2013.

[12] Zulkarnain, "Pendidikan Karakter sebagai Sarana Pembangunan Nilai Kerendahan Hati dan Toleransi Tinjauan Al-Qur'an,” Jurnal Waskita, vol. 1, no. 1, pp. 61-76, 2017.

[13] T. Lickona, Educating For Character, How Our Schools Can Teach Respect and Responsibility, New York: Bantam Book, 1992.

[14] A. Suryadi, Sebuah Model Pendidikan Karakter dalam Sistem Persekolahan di Indonesia, dalam Potret Profesionalisme Guru dalam membangun Karakter Bangsa: Pengalaman Indonesia dan Malaysia, Bandung: UPI Press, 2010.

[15] D. Kesuma, dkk., Pendidikan Karakter, Kajian Teori dan Praktek di Sekolah, Bandung: Remaja Rosdakarya, 2011.

[16] J.A. Banks, Multicultural Education, Issues and Perspectives, BostonLondon: Allyn and Bacon Press, 1989.

[17] R. Gonibala, "Pendidikan Berbasis Multikultural sebagai Modal Sosial Kerukunan Umat Beragama (Konteks Sulawesi Utara)," Jurnal Potret Pemikiran, vol. 17, no. 2, pp. 275-287, 2013.

[18] J.W. Creswell, Research Design, Quantitative \& Qualitative Approaches. Sage Publications. Alih bahasa oleh: Angkatan III \& IV KIK UI bekerjasama dengan Nur Khabibah. (2002). Jakarta: KIK Press, 1994.

[19] Sugiyono, Metode Penelitian Kuantitatif, Kualitatif dan R\&D. Bandung: Alfabeta, 2006. 